\title{
Study on the Parameter Characteristics of Thermal Water Jet Nozzles
}

\author{
Jianzhao Zhou ${ }^{1}$, Liqun Han ${ }^{1}$ \\ ${ }^{1}$ PLA Univ. of Sci. \& Tech., Nanjing, Jiangsu, 210007, China
}

\begin{abstract}
KEYWORD: contraction angle of nozzle; length-diameter ratio of nozzle; nozzle diameter flow temperature; target distance

ABSTRACT: There are series of car accidents and thousands of losses because of icy roads in cold weather. So thermal water-jet cutting and mechanical milling deicing technology is developed and researched.It means that road is jetted with hot water and then the ice is removed by using milling cutter. The shape and the parameters of the nozzle have a great effect on the test. So,the effect of straight cone nozzles contraction angle and the effect of the length-diameter ratio L/d of straight cone nozzles on jet flow field are analyzed. The nozzle diameter, the flow temperature, the target distance and the jet angle are all tested in the deicing influence and the optimal parameters are concluded.
\end{abstract}

\section{INTRODUCTION}

There are many areas suffered from ice and snow in china every winter, many highways are covered by ice and snow, and it is prone to cause major traffic accidents. Effective measures must be taken to clean the snow and ice on the road or it will cause huge losses ${ }^{[1][2]}$. Road de-icing technology and equipment have developed a lot at home and abroad, but it is difficult to synthesize the advantages of high efficiency, good effect and low cost. Although chemical ablation method can significantly inhibit the road snow and ice and prevent secondary freezing, but its harm to environment is too significant to ignore. Artificial remove method has the disadvantages of high cost, low efficiency, long operation time and the effect on the efficiency of road traffic, so it cannot effectively deal with the emergency and contingency. Compared with the artificial method, mechanical method has a higher de-icing speed, high efficiency, without having to spend a lot of manpower[3]. However, due to the limitations of mechanical design itself, the purge rate is low. So this paper presents a deicing method which combines mechanical compound devices and thermal water jet technology.

Thermal water jet de-icing technique is a new type of road deicing technology, which combines thermal melting technology with water jet cleaning technology. On the one hand, it goes deep into ice crack with the aid of high pressure water and the pressure keeps increasing in the meantime. When the pressure is greater than the surface adhesion between ice, ice and road, there are crack between ice and the ground and within ice. In subsequent fracturing, shear, wedge under the action of water jet, ice and pavement completely separate, and there are complete rupture between ice, achieving the goal of crushed ice ${ }^{[4]}$. On the other hand, it takes advantages of heat energy, carried by the jet flow, to melt the ice on the road and reduce surface adhesion between ice, ice and road, so as to improve the efficiency of the water jet cleaning. In the thermal water jet of mechanical milling deicer, water jet cutting of ice is an important link in the whole process of de-icing and the size and the shape of the nozzle have an important influence on speed and pressure of the flow field ${ }^{[5]}$. 


\section{THE ANALYSIS OF THE EFFECT OF STRAIGHT CONE NOZZLES CONTRACTION ANGLE ON JET FLOW FIELD}

The nozzle structure is shown in figure 1:

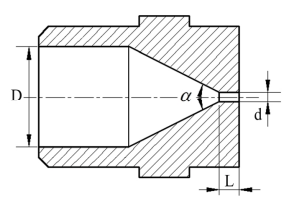

Fig1.The internal structure of straight cone nozzles

According to its internal shape, water jet nozzle can be divided into cone shape, straight cone shape etc. The latter is widely used, due to their large flow coefficient. In order to cut ice into independent piece, this paper presents nozzles as shown in figure 1.D is inlet diameter, $\mathrm{d}$ is orifice diameter, $\mathrm{L}$ is the extension length of the orifice, and $\alpha$ is the concentration angle. When others parameters is assumed, single variable method is applied to study the effect of the structure parameters $(\mathrm{d}$ or $\alpha)$ on the flow field characteristics.

As shown in Fig 2, for the straight cone nozzle, inlet boundary IN is $\mathrm{AB}$, the outlet boundary OUT is CD, DE and FE, the nozzle wall boundary WALL is set as BL,LK,KJ,JI,IH, HG and GC, and the symmetry axis is AF. When the target distance is $7 \sim 8 \mathrm{~cm}$, jet has good coherence and integration. So in thermal water jet de-icing devices, the target distance between nozzle and the ice is designed to be $7 \sim 8 \mathrm{~cm}$, thus the basic size of the external flow field established in the ICEM CFD is $50 \times 100 \mathrm{~mm}^{[6]}$.

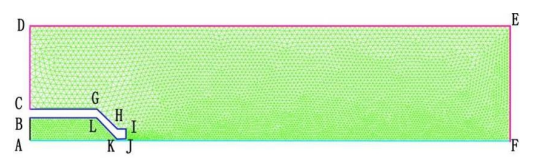

Fig2. External and internal flow field meshing of straight cone nozzle

According to the inlet speed of nozzle, inlet pressure can be calculated. In combination with jet diameter $1 \mathrm{~mm}$, the Reynolds number can be calculated and $\operatorname{Re}>\operatorname{Recr}[7]$. Thus, the flow regime of jet flow is turbulence. Given the incompressibility of water, for the turbulence, the control equation expressed in tensor form is as follows:

$$
\begin{aligned}
& \frac{\partial}{\partial x_{i}}\left(\rho u_{i}\right)=0 \\
& \frac{\partial u_{i}}{\partial t}+\frac{\partial}{\partial x_{j}}\left(u_{i} u_{j}\right)=\frac{1}{\rho} \frac{\partial p}{\partial x_{i}}+\frac{\partial}{\partial x_{j}}\left(v \frac{\partial u_{i}}{\partial x_{j}}-\overline{u_{i}^{\prime} u_{j}^{\prime}}\right)
\end{aligned}
$$

In the formula, $u_{i}$ and $u_{j}$ represent for speed vector of point $\mathrm{i}$ and $\mathrm{j}$ respectively. ${ }_{i}^{\prime}$ and $u_{j}^{\prime}$ represent for acceleration vector of point $i$ and $j$ respectively. Because the cross sectional area of nozzle outlet contracts sharply, when the fluid runs across the point, it keeps in high turbulent state. Standard $\kappa-\varepsilon$ equation is applied.

Firstly, Analyze contraction anglea. The length-diameter ratio (L/d) is set to 2 . When contraction angle $\alpha$, changes from $35^{\circ}$ to $20^{\circ}$.In order to express the flow field change more clearly, here take every $50^{\circ}$ decline to analyze the results.

From figures above, when the contraction angle changes from $35^{\circ}$ to $20^{\circ}$, there are obvious changes in the axial speed field. The maximum of axial speed increases from $221 \mathrm{~m} / \mathrm{s}$ to $226 \mathrm{~m} / \mathrm{s}$ at first, and then decreases to $209 \mathrm{~m} / \mathrm{s}$. Its change rules satisfy curve as follows: 


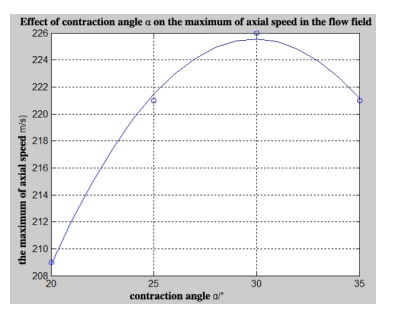

Fig3. Effect of contraction angle $\alpha$ on the maximum of axial speed in the flow field

As can be seen from the figure 3 , when the contraction angle is $30^{\circ}$, the maximum axial speed of jet flow field is about $225.5 \mathrm{~m} / \mathrm{s}$, which is referred to as the best value.

\section{THE EFFECT OF THE LENGTH-DIAMETER RATIO L/D OF STRAIGHT CONE NOZZLES ON JET FLOW FIELD}

According to the existing nozzle size on the market, the length-diameter ratio $\mathrm{L} / \mathrm{d}$ is set to changes from 1 to 3 . In order to express the flow field change more clearly, here take every 0.5 increment to analyze the results.

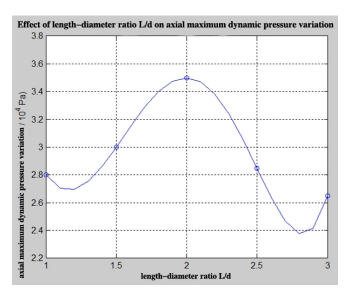

Fig4.Effect of length-diameter ratio L/d on axial maximum dynamic pressure variation

As can be seen from figures above, when the length-diameter ratio changes from 1 to 3 , the curves of axial dynamic change obviously. The axial maximum dynamic pressure variation increases from about $2.8 \times 10^{4} \mathrm{~Pa}$ to $3.5 \times 10^{4} \mathrm{~Pa}$ at first and then decreases to about $2.6 \times 10^{4} \mathrm{~Pa}$. Its change rules satisfy curve as follows. As can be seen from figures 4, when the length-diameter ratio equals to 2 , the axial maximum dynamic pressure variation reaches the maximum.

\section{THE EFFECT OF NOZZLE DIAMETER ON THE THROUGHPUT AND SPEED OF JET FLOW}

In the experiment, straight cone nozzles of different diameter are used, the concentration angle is assumed to be $30^{\circ}$, and the length-diameter ratio is 2 . The average jet throughput $q$ and speed $v$ are measured as table 1 .

Table 1. The average jet throughput and speed of different nozzle diameters

\begin{tabular}{ccc}
\hline $\begin{array}{c}\text { Nozzle } \\
\text { diameter } \\
\mathrm{d} / \mathrm{mm}\end{array}$ & $\begin{array}{c}\text { Average } \\
\text { throughput } \\
\mathrm{q} /(\mathrm{ml} / \mathrm{s})\end{array}$ & $\begin{array}{c}\text { Average } \\
\text { speed } \\
\mathrm{v} /(\mathrm{m} / \mathrm{s})\end{array}$ \\
\hline 0.50 & 9.841 & 45.12 \\
0.75 & 17.516 & 39.65 \\
1.00 & 25.384 & 37.32 \\
1.25 & 41.07 & 35.65 \\
1.50 & 42.50 & 34.05 \\
1.75 & 59.33 & 34.66 \\
2.99 & 116.98 & 33.45 \\
\hline
\end{tabular}


By plotting and curve fitting the above data, fitting curve is available as shown in figure 5, 6 . As can be seen from the figure 5, with the increase of nozzle diameter, outlet flow throughput increases as a whole. When the diameter $\mathrm{d}$ is $0.5 \sim 1.5 \mathrm{~mm}$, flow curve appears a crest and the peak throughput is about $45 \mathrm{ml} / \mathrm{s}$, corresponding to the nozzle diameter is about $1.25 \mathrm{~mm}$. When the nozzle diameter is $1.5 \sim 1.75 \mathrm{~mm}$, flow curve appears a trough, its value is about $41 \mathrm{ml} / \mathrm{s}$. When the nozzle diameter is greater than $1.75 \mathrm{~mm}$, there is a break and the trend is rising abruptly.

As can be seen from the figure 6 , with the increase of nozzle diameter, outlet speed decreases as a whole. When the diameter $\mathrm{d}$ is $0.5 \sim 2.0 \mathrm{~mm}$, the average speed of jet flow drops from $45 \mathrm{~m} / \mathrm{s}$ to $33.5 \mathrm{~m} / \mathrm{s}$. When the nozzle diameter is $1.0 \sim 1.5 \mathrm{~mm}$, jet flow curve of average outlet speed drops smoothly and its speed value is about $35 \mathrm{~m} / \mathrm{s}$. When the nozzle diameter is greater than $1.5 \mathrm{~mm}$, the speed drops continuously.

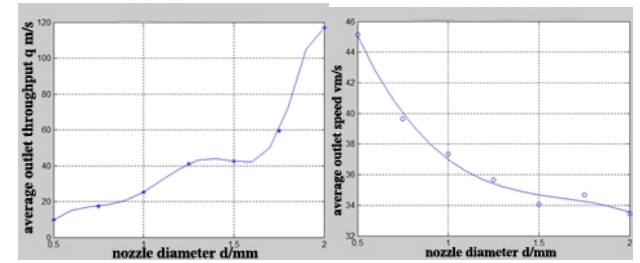

Fig 5 The curve of average outlet throughput q changing with nozzle diameter d Fig 6 The curve of average outlet speed $v$ changing with nozzle diameter $\mathrm{d}$

Synthesize the above experimental results: when the diameter $\mathrm{d}$ is $0.5 \sim 1.5 \mathrm{~mm}$, flow curve appears a peak and the peak throughput is about $45 \mathrm{ml} / \mathrm{s}$, corresponding to the nozzle diameter is about $1.25 \mathrm{~mm}$; When the nozzle diameter is $1.0 \sim 1.5 \mathrm{~mm}$, the average outlet speed appears a decline in relatively flat stage, and the speed keeps in about $35 \mathrm{~m} / \mathrm{s}$, corresponding to the nozzle diameter is about $1.25 \mathrm{~mm}$. Therefore, the optimal water jet nozzle diameter $\mathrm{d}$ is determined to be $1.25 \mathrm{~mm}$.

\section{THE EFFECT OF FLOW TEMPERATURE ON DE-ICING SPEED}

In order to study the effect of flow temperature on the deicing speed (the volume of ice melts in unit time, namely $\mathrm{cm}^{3} / \mathrm{s}$ ), this section refers jet temperature as the only controllable variables to provide reference data for optimum de-icing temperature. When the booster pump keeps normal operation, experiments are conducted.

In the experiment, heat the water to $45{ }^{\circ} \mathrm{C}$ and keep the temperature in $45 \sim 50{ }^{\circ} \mathrm{C}$. After each group of test, temperature will increased by $10{ }^{\circ} \mathrm{C}$. Finally, when the water temperature increased to $95{ }^{\circ} \mathrm{C}$, the last set of tests are carried out. Test data are shown in table 2 below: 
Table 2. The effect of flow temperature on the de-icing speed

\begin{tabular}{cccc}
\hline $\begin{array}{c}\text { Flow } \\
\text { tempera } \\
\text { ture } \\
\mathrm{T} /{ }^{\circ} \mathrm{C}\end{array}$ & $\begin{array}{c}\text { Nozzle } \\
\text { diameter } \\
\mathrm{d} / \mathrm{mm}\end{array}$ & $\begin{array}{c}\text { Target } \\
\text { distance } \\
L / \mathrm{cm}\end{array}$ & $\begin{array}{c}\text { de-icing } \\
\text { speed } \\
\mathrm{V} / \mathrm{cm}^{3} / \mathrm{s}\end{array}$ \\
\hline $\begin{array}{c}45 \sim 50^{\circ} \\
\mathrm{C}\end{array}$ & 1.25 & 10 & 8.6337 \\
$\begin{array}{c}55 \sim 60^{\circ} \\
\mathrm{C}\end{array}$ & 1.25 & 10 & 8.990 \\
$\begin{array}{c}65 \sim 70^{\circ} \\
\mathrm{C}\end{array}$ & 1.25 & 10 & 10.8081 \\
$\begin{array}{c}75 \sim 80^{\circ} \\
\mathrm{C}\end{array}$ & 1.25 & 10 & 12.8231 \\
$\begin{array}{c}85 \sim 90^{\circ} \\
\mathrm{C}\end{array}$ & 1.25 & 10 & 19.4938 \\
$\begin{array}{c}90 \sim 95^{\circ} \\
\mathrm{C}\end{array}$ & 1.25 & 10 & 15.4517 \\
\hline
\end{tabular}

Through Matlab, fitting curve is shown in figure 6.

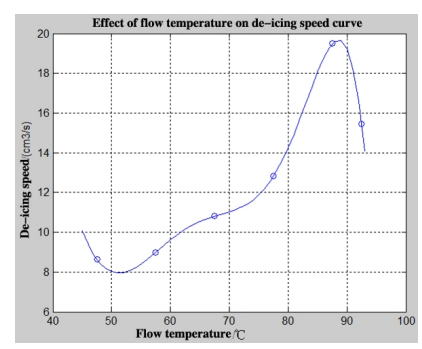

Fig 6. The effect of flow temperature on de-icing speed curve

Through the fitting curve it can be concluded: when de-icing temperature is $88 \sim 93{ }^{\circ} \mathrm{C}$, the average speed of deicing is the largest.

\section{THE EFFECT OF TARGET DISTANCE ON DE-ICING SPEED}

When thermal jet device is placed on the road, the vertical distance between the nozzle outlet and ice is the target distance, as shown in figure 7.

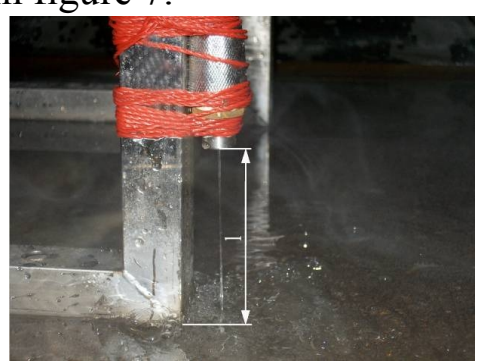

Fig 7.Target distance 
Table 3. the test results of nozzle target distance

\begin{tabular}{|c|c|c|c|c|c|}
\hline \multicolumn{2}{|c|}{$\begin{array}{l}0.75 \mathrm{~mm} \\
\text { nozzle }\end{array}$} & \multicolumn{2}{|c|}{$\begin{array}{l}1.00 \mathrm{~mm} \\
\text { nozzle }\end{array}$} & \multicolumn{2}{|c|}{$1.25 \mathrm{~mm}$ nozzle } \\
\hline $\begin{array}{l}\text { Targe } \\
\mathrm{t} \\
\text { dista } \\
\text { nce } \\
\mathrm{L} / \mathrm{cm}\end{array}$ & $\begin{array}{l}\text { De-ic } \\
\text { ing } \\
\text { spee } \\
\mathrm{d} \\
\mathrm{V} / \mathrm{cm} \\
3 / \mathrm{s}\end{array}$ & $\begin{array}{l}\text { Targe } \\
\mathrm{t} \\
\text { dista } \\
\text { nce } \\
L / \mathrm{cm}\end{array}$ & $\begin{array}{l}\text { De-ic } \\
\text { ing } \\
\text { spee } \\
\mathrm{d} \\
\mathrm{V} / \mathrm{cm} \\
3 / \mathrm{s}\end{array}$ & $\begin{array}{l}\text { Targe } \\
\mathrm{t} \\
\text { dista } \\
\text { nce } \\
L / \mathrm{cm}\end{array}$ & $\begin{array}{l}\text { De-icing } \\
\text { speed } \\
/ \mathrm{cm}^{3} / \mathrm{s}\end{array}$ \\
\hline $\begin{array}{l}4.5 \\
6.0\end{array}$ & $\begin{array}{l}1.178 \\
5 \\
1.542\end{array}$ & $\begin{array}{l}9.0 \\
10.5\end{array}$ & $\begin{array}{l}1.482 \\
1.594 \\
5\end{array}$ & $\begin{array}{l}8.5 \\
10.0\end{array}$ & $\begin{array}{l}2.3436 \\
2.4666\end{array}$ \\
\hline 7.5 & $\begin{array}{l}1.298 \\
8\end{array}$ & 12.17 & $\begin{array}{l}1.447 \\
7\end{array}$ & 11.5 & 2.336 \\
\hline 9.3 & $\begin{array}{l}1.832 \\
9\end{array}$ & 13.5 & $\begin{array}{l}1.481 \\
4\end{array}$ & 13.1 & 2.259 \\
\hline 10.0 & 1.557 & 14.5 & $\begin{array}{l}1.464 \\
4\end{array}$ & 14.5 & 2.2913 \\
\hline
\end{tabular}

Based on the previous research results, the diameter $\mathrm{d}$ of nozzle chosen is $1.25 \mathrm{~mm}$, length-diameter ratio $\mathrm{L} / \mathrm{d}$ is 2 . In order to compare, this section also selects the nozzles whose diameter $\mathrm{d}$ is $0.75 \mathrm{~mm}$ and $1.0 \mathrm{~mm}$, test apparatus as shown in figure 9 . Based on the principles of a single variable, when other controllable external conditions are unchanged and booster pump works steadily, change the nozzle target distance to conduct experiment and the results are shown in table 3. Using Matlab to the above-mentioned data, fitting curve is available.

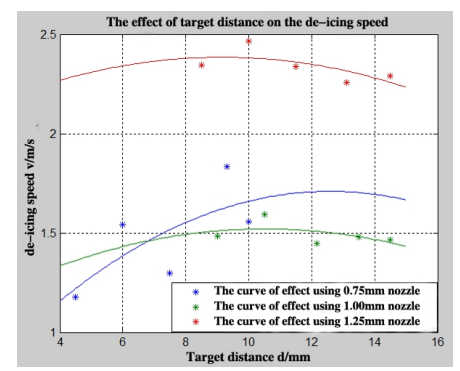

Fig 8. The effect of target distance on the de-icing speed

It is revealed from the figure 9 that de-icing speed of a $1.25 \mathrm{~mm}$ nozzle is significantly greater than $0.75 \mathrm{~mm}$ and $1.0 \mathrm{~mm}$. When the target distance changes from $4 \mathrm{~cm}$ to $16 \mathrm{~cm}$, the de-icing speed curve of three kinds of nozzles appears a peak. For $1.25 \mathrm{~mm}$ and $1.0 \mathrm{~mm}$ nozzle, the target distance which corresponds to the biggest de-icing speed is about $10 \mathrm{~cm}$. For $0.75 \mathrm{~mm}$ nozzle, it is about $13 \mathrm{~cm}$.

\section{THE EFFECT OF JET ANGLE ON DE-ICING SPEED}

Jet angle refers to the angle between the axis of the jet nozzle and the vertical direction of the device, as shown in the figure below. When the pointing direction of the nozzle corresponds to the advancing direction of the device, the jet Angle is positive, on the contrary, it is negative. In the same way, using the previous research results, this section mainly do research on the jet angle of $1.25 \mathrm{~mm}$ nozzle. 


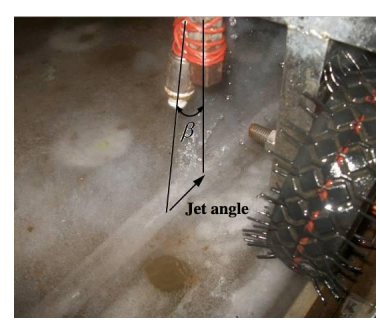

Fig 9.Jet angle $\beta$

Also, according to the principle of controllable variables, when the nozzle diameter is $1.25 \mathrm{~mm}$, nozzle concentration angle is $30^{\circ}$, length- diameter ratio $\mathrm{L} / \mathrm{d}$ is 2 , jet target distance is $10 \mathrm{~cm}$, and jet temperature controls between 88 and 93. When the booster pump works under the steadily condition, change the jet angle, to test the data are as follows:

Table 4.the effect of jet angle $\beta$ on de-icing speed

\begin{tabular}{ccc}
\hline $\begin{array}{c}\text { Nozzle } \\
\text { angle } \beta /{ }^{\circ}\end{array}$ & $\begin{array}{c}\text { Nozzle } \\
\text { diameter } \mathrm{d} / \mathrm{mm}\end{array}$ & $\begin{array}{c}\text { De-icing speed } \\
\mathrm{V} / \mathrm{cm}^{3} / \mathrm{s}\end{array}$ \\
\hline-20 & 1.25 & 1.8672 \\
-10 & 1.25 & 2.0223 \\
0 & 1.25 & 2.4666 \\
10 & 2.25 & 2.5087 \\
20 & 1.25 & 2.5232 \\
30 & 1.25 & 2.4563 \\
40 & 1.25 & 2.2023 \\
\hline
\end{tabular}

Fitting the data above, figure 10 is available.

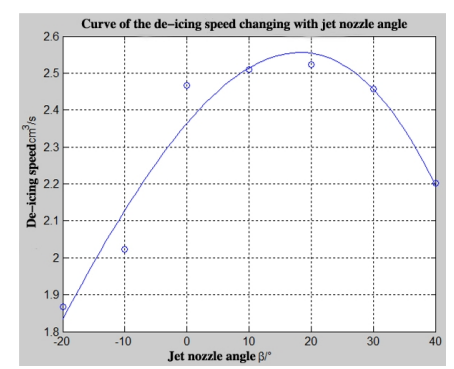

Fig 10.The fitting curve of the de-icing speed changing with jet nozzle angle $\beta$

It can be seen from figure 11: when the jet nozzle angle ranges from $-20^{\circ}$ to $40^{\circ}$, the curve of de-icing speed appears a peak and its relative jet angle is about $20^{\circ}$.

\section{CONCLUSION}

To sum up, main parameters of thermal water jet device are listed as table 5: 
Table 5. main parameters of thermal water jet device

\begin{tabular}{|c|c|c|c|c|c|c|}
\hline $\begin{array}{c}\text { Nozzle } \\
\text { type }\end{array}$ & $\begin{array}{l}\text { Optim } \\
\text { al } \\
\text { conce } \\
\text { ntratio } \\
\mathrm{n} \\
\text { angle } \\
\alpha\end{array}$ & $\begin{array}{l}\text { Optim } \\
\text { al } \\
\text { length } \\
\text {-diame } \\
\text { ter } \\
\text { ratio } \\
\text { L/d }\end{array}$ & $\begin{array}{c}\text { Opti } \\
\text { mal } \\
\text { noz } \\
\text { zle } \\
\text { dia } \\
\text { met } \\
\text { er d }\end{array}$ & $\begin{array}{c}\text { Opti } \\
\text { mal } \\
\text { de-ic } \\
\text { ing } \\
\text { temp } \\
\text { eratu } \\
\text { re } \\
\mathrm{T}\end{array}$ & $\begin{array}{c}\text { Opt } \\
\text { ima } \\
1 \\
\text { targ } \\
\text { et } \\
\text { dist } \\
\text { anc } \\
\text { e } \\
l \\
\end{array}$ & $\begin{array}{c}\text { Opti } \\
\text { mal } \\
\text { jet } \\
\text { angl } \\
\mathrm{e} \\
\beta\end{array}$ \\
\hline $\begin{array}{c}\text { Straight } \\
\text { cone } \\
\text { nozzle }\end{array}$ & $30^{\circ}$ & 2 & 1.25 & $\begin{array}{l}89 \sim \\
93^{\circ} \mathrm{C}\end{array}$ & $\begin{array}{c}10 \mathrm{c} \\
\mathrm{m}\end{array}$ & $20^{\circ}$ \\
\hline
\end{tabular}

\section{REFERENCE}

[1]Zhou Jian-zhao,Li Cong,et al.The research and development of road rapid deicing units by using thermal-water jet[J]. Mechanical design and manufacturing:2012,8:113-115

[2]Jianzhao Zhou, Siwei Lai, Xiaopan Xu, Ed. R\&D of Equipment for Deicing by Thermal Water-jet and Mechanical Deicing Method [C]. IEEE Int. Conf. on Applied Mechanics, Materials and Manufacturing: Changchun, China, 1288-1293 November 2012

[3] Zhao Jun-ying.The theoretical analysis and numerical simulation research of high pressure abrasive water jet technology[D]. Taiyuan:Taiyuan university of technology,2008.5

[4]Isobe E., Minada J.Development of Long-term Under ground Thermal Energy Storage Road Way Snow-melting System [C]. New Challenges for Winter Road Service: 11th International Winter Road Congress, 2002

[5]Zhao Jun,Wang Huajun,Ed. Seasonal Behavior of Pavement in Geothermal Snow-melting System with Solar Energy Storage [J].Transactions of Tianjin University: 2006, Vol. 12(5): 319-324 [6]Zhang Mei-jun,Cao Qin.Engineering machinery dynamics[M],Beijing:National defence industry press, 2012

[7]Uchino A., OhtakeH., Kawai H.Performance Evaluation of Heat Storage in Summer Season and Snow Melting in Winter Season by Snow Melting System Using a Ground Souse Heat Pump[J].Memoirs of the Hokkaido Institute of Technology;2006,No.34:149-154 